\title{
National Injustice, Caring Institutions and Cosmopolitan Motivation
}

\author{
Joshua Hobbs ${ }^{1}$
}

Accepted: 30 June 2021 / Published online: 13 July 2021

(C) The Author(s) 2021

\begin{abstract}
This paper examines the relationship between strategies of cosmopolitan education intended to motivate citizens of affluent countries to care about distant others facing injustice, and injustices within the borders of these affluent countries. I argue that promoting justice within affluent countries and motivating citizens to act to address global injustices, are potentially complementary rather than competing projects. I make two claims. (i) Injustices within national borders can undermine the development of cosmopolitan concern. (ii) National institutions delivering health and social care play a vital role in developing and sustaining affective dispositions necessary to care about the fate of distant others.
\end{abstract}

Keywords Cosmopolitanism $\cdot$ Motivation $\cdot$ Homelessness $\cdot$ Empathy $\cdot$ Sentimental cosmopolitanism

\section{Introduction}

Motivating individuals in the more affluent communities of the world to act to address global injustices has rightly become an important topic in the global justice literature. As a number of scholars, of varying degrees of sympathy for duties to address global injustices, have identified, these duties face a 'motivation gap' (Lenard 2010; Straehle 2016; Woods 2012). This is to say that, despite some agreement over the existence of these duties, they struggle to motivate action-even in those who assent to them (Lenard 2010). In response to this focus on motivation, there has been an increased interest in the work that sentiment can do in connecting individuals to distant others, leading them to identify more readily with these others, and act to address the injustices that they face. At the centre of this 'turn to affect' has been a growing project of 'sentimental cosmopolitanism' (Long 2009; Woods

Joshua Hobbs

J.J.Hobbs@Leeds.ac.uk

1 Interdisciplinary Ethics Applied Centre (IDEA), University of Leeds, 17 Blenheim Terrace,

Leeds LS2 9JT, UK 
2012). Sentimental cosmopolitans argue that a cosmopolitan sentimental education, prioritising literature, narrative art and news media featuring sympathetic portrayals of distant others, offers a promising means by which to encourage individuals in more affluent countries to care about the fate of these others and act to address the injustices that they face (Long 2009; Nussbaum 2001; Woods 2012). However, sentimental cosmopolitan authors have had little to say about the injustices that exist within the borders of these affluent countries themselves. At a time when levels of inequality and rates of homelessness are rising rapidly in many affluent countries (Burgi 2014; Rummery 2016), accompanied by an increasing nationalism and parochialism within political debate globally (Goodwin et al. 2016; Posner 2017), this lack of discussion is particularly significant.

This paper addresses this omission, and examines the relationship between attempts to motivate the citizens of more affluent countries to care about the fate of distant others facing severe injustices, such as global poverty, and levels of injustice within the borders of these affluent countries themselves. I aim to show that the promotion of justice within the borders of more affluent countries and strategies of cosmopolitan sentimental education aimed at motivating support for action to address global injustices are potentially complementary rather than competing projects. In order to do so, I defend two claims concerning the relationship between national injustice and cosmopolitan motivation-one negative and one positive. (i) Injustice within national borders can undermine the development of cosmopolitan concern and respect for the universal values that underlie cosmopolitanism more broadly. (ii) Institutions within national borders responsible for delivering health and social care play a vital role in developing and sustaining the empathetic or compassionate dispositions necessary for individuals in more affluent countries to care deeply about the fate of distant others. Therefore, sentimental cosmopolitans ought to be concerned with addressing injustices within the borders of more affluent countries, not only due to the intrinsic value of doing so, but also as a means to develop and sustain the affective dispositions necessary to motivate citizens to act to address injustices elsewhere. The argument of the paper will focus on the context of the European welfare state, and the United Kingdom in particular. Because of the non-ideal nature of the theorising, it is necessary for the discussion to engage with a specific case, and the UK domestic context is the one I am most familiar with, both as a researcher and a citizen.

Before I begin it is necessary to make a brief comment on methodology. The questions the article addresses span the divide between the empirical and the normative. In these circumstances, as Emily McTernan notes, 'empirical research has a role to play within political philosophy, and a role that does not involve merely paying lip-service to the possibility that empirical research could be relevant, but instead active engagement with that empirical research' (McTernan 2014, p. 104). These are normative questions that cannot be answered without attention to empirical research; however, neither can they be answered by the employment of empirical methods, or attention to empirical research alone. To some the argument of the article may feel somewhat speculative, whereas to others it may seem overly empirical. Striking this balance is difficult but necessary, in order to engage with normative issues of a non-ideal nature. 


\section{Sentimental Cosmopolitanism}

Sentimental cosmopolitanism is a broad body of theory. Primarily associated with the early work of Martha Nussbaum (2001), the sentimental cosmopolitan project has developed into a unified theoretical and practical project, with advocates in Political Theory (Long 2009; Woods 2012) and International Relations (Jeffery 2014). Graham Long defines sentimental cosmopolitanism 'as a certain configuration of our sentiments and interests, through which we identify more readily with people regardless of where in the world they are' $(2009$, p. 330). Although differing in some respects, the work of sentimental cosmopolitan theorists shares the following four features.

First, these theorists foreground the role of empathy or compassion, understood as feeling for others-i.e. caring about their welfare-in motivating moral action (Long 2009, p. 317). This is a claim that receives support from the empirical literature on moral motivation (Prinz and Nichols 2010; Greene et al. 2001; Izard and Ackerman 2000). As a wide ranging meta-study on the topic notes, a weight of evidence suggests that 'not only are emotions engaged during moral cognition, but that emotions... are in fact critical for human morality' (Young and Koenigs 2007, p. 69). Although the exact terminology differs between theorists, the sentiment that they discuss can be captured by Daniel Batson's account of empathetic concern, understood as 'an other-orientated emotional response congruent with the perceived welfare of another person' (Batson et al. 1995, p. 1042). Second, these accounts share a commitment to moral cosmopolitanism, and argue that motivating action to address global injustices requires cultivating empathy or compassion on the part of citizens of the more affluent communities of the world for distant others facing injustices. Third, in order to achieve the extension of empathy or compassion to individuals and groups beyond national borders, sentimental cosmopolitans recommend a process of cosmopolitan sentimental education. In this process, a global focus within formal education, and exposure to sympathetic portrayals of distant others in literature and narrative art and news media, serve to encourage individuals in more affluent countries to care about the fate of individuals beyond national borders and act to address global injustice (Long 2009; Nussbaum 1996; Woods 2012). Fourth, although emphasising the motivational role of emotions, sentimental cosmopolitan accounts share a broadly Aristotelian view of emotion, where emotions are not simply blind urges, but contain rational elements, and can be evaluated for their appropriateness, correctness or fittingness (Tiberius 2015, p. 74; Nussbaum 2001, pp. 46-47). On this view, both reason and emotion are held to play necessary and complementary roles in moral life, with reason determining the content of our duties and emotion motivating compliance with these duties (Long 2009, p. 330; Woods 2012, p. 40). Following Aristotle, sentimental cosmopolitans argue that as emotions are not blind urges, but contain rational elements, they can be educated, both through processes of habituation (Kristjansson 2014) and the influence of critical reason (Woods 2012). As Nussbaum suggests in the case of compassion, 'since compassion contains thought it can be educated' (1996, p.13). 
This emphasis on emotion should not be taken to imply that sentimental cosmopolitans consider arguments to have no useful role to play in motivating action to address poverty and other global injustices (Rorty 1998, p. 125). Rather, the relationship between affective concern for individuals facing poverty and moral arguments to this effect is held to be a circular one; where affective concern allows for the motivational force of arguments to gain purchase, which in turn can deepen levels of motivation to address global poverty. However, for this relationship to operate there needs to be at least a minimum level of affective concern present for the subject of the argument. As Woods argues, 'moral argument has no purchase if it cannot latch on to something that is present in the agent's motivational set' (2012, p. 36).

The paper begins from the assumption that sentimental cosmopolitanism is broadly correct, and, as such, will not question the validity of these four claims. Instead, I focus on the neglected issue of levels of injustice within the more affluent communities, where projects of sentimental education are to be enacted, and their relevance for the success of the sentimental cosmopolitan project. In focusing on this issue, I do not mean to suggest that sentimental cosmopolitan is an entirely unidirectional project, where the affluent are encouraged to care for 'suffering distant others', who sit without agency waiting for rescue, and whose cosmopolitan dispositions (or otherwise) are of no interest. Nevertheless, as a means to address global injustices, such as global poverty - the primary focus of sentimental cosmopolitan literature (Long 2009, p. 318) — the project necessarily places greater emphasis, at least in the short term, on motivating citizens of the more affluent communities of the world to act. This is not simply because these individuals have disposable income that may be donated to aid organisations acting to address global poverty or other injustices. Rather, as citizens of powerful nations that plausibly bear some responsibility for the current international order (Pogge 2002), that are generally internally democratic, these individuals are well-placed to agitate for political change to remedy global injustices. ${ }^{1}$ Finally, although this paper focuses on the literature on sentimental cosmopolitanism, my argument is of relevance for others who consider the extension of empathy or compassion to distant others to be necessary for, or conducive to, motivating action to address global injustices.

\section{National Injustice and Cosmopolitan Values}

Judith Shklar observes that 'when justice and fairness do prevail they are undramatic'; rather it is experience of injustices, and the resulting suffering, that leaves the more significant emotional impression (Shklar 1990, p. 112). This negative focus is particularly important in examining how conditions within national borders affect citizens' receptiveness to cosmopolitanism, as it is arguably our encounters with injustice rather than with justice that have the more powerful emotional impact. Taking its cue from Shklar's observation, this section of the paper argues that injustices

\footnotetext{
1 Moreover, these citizens may be to some extent complicit in an unjust world order that is plausibly responsible for much global poverty and other injustices.
} 
within the borders of more affluent countries are of particular relevance to the sentimental cosmopolitan project, as they can actively undermine the extension of cosmopolitan concern amongst the citizenry. I aim to show that tolerance of persistent visible injustices within national borders, by both fellow citizens and the state, can have a didactic effect, serving to undermine respect for the universal values that underlie cosmopolitanism. I illustrate this through the case of homelessness, a prevalent and visible injustice within more affluent countries.

\section{Homelessness as Sentimental Miseducation}

For strategies of cosmopolitan sentimental education to be effective, sentimental cosmopolitan theorists argue that not only must individuals be taught cosmopolitan values, but that these values must also be backed up by corresponding affective commitments in order for them to reliably motivate action (Woods 2012, p. 36). This is not to suggest that we must feel the affective force of these duties directly, but that these duties must be broadly supported by our affective dispositions. I want to suggest that tolerance of injustices within a society can function as a sort of cosmopoli$\tan$ miseducation, serving to undermine commitments to universal values and the affective dispositions conducive to the pursuit of these values. Individual behaviour and institutional arrangements that ignore, or fail to address, instances of significant injustice within national borders can perform an expressive function, sending out a message that directly contradicts the universal values on which cosmopolitanism is based. This is particularly significant, because social psychology research suggests that descriptive norms - those deriving from observed behaviour-are often taken as a more authoritative source of moral instruction than injunctive norms-those communicated through didactic processes (Campbell-Arvai et al. 2014).

To illustrate, consider the example of homelessness, a particularly visible form of injustice that is tolerated to various degrees within the richer communities of the world. ${ }^{2}$ Tolerance of homelessness within more affluent countries sends a message at odds with respect for the universal values that underlie cosmopolitanism. Where behaviour is taken as authoritative, this may undermine acceptance of these values. As this is a work of normative political theory, discussion of this mechanism is necessarily speculative. However, empirical research suggests that popular support for foreign aid spending (European Commission 2005) is correlated with low levels of domestic homelessness (Ortiz-Ospina and Roser 2017). Similarly, popular support for foreign aid is negatively tied to levels of domestic inequality (Chong and Gradstein 2006). While, it is important to note that correlation is not causation, these studies suggest that the mechanism outlined is, at least, prima facie plausible.

However, it is important to note two things here. (i) Homelessness is necessarily a complex phenomenon, and some homeless individuals and families exist out of sight

\footnotetext{
${ }^{2}$ It might be objected that some countries with relatively low levels of homelessness are highly communitarian and display relatively low levels of cosmopolitan concern, as perhaps reflected in a lack of public support for public spending on international development or acceptance of refugees. I do not want to deny these cases exist; however, my primary focus here is British/European welfare states.
} 
in temporary and insecure accommodation. Nevertheless, I take homelessness to constitute a particularly visible form of injustice in most instances. (ii) I accept that some people may consider homelessness to be compatible with the pursuit of justice, or even to be a necessary condition for this project, especially those who favour a libertarian account of justice. The argument of this article does not directly speak to these people. However, I will also offer some reasons for thinking that actually existing homelessness is inconsistent with libertarian justice in, at least, the majority of cases.

The most direct mechanism through which this process can occur is by individuals witnessing this behaviour in person as passers-by on the street. Where individuals see others routinely ignoring homeless people when they encounter them on the street, this behaviour has an expressive function. From a normative perspective the most significant expressive aspect of this behaviour may be what this communicates to homeless individuals themselves, as where homeless individuals are ignored in person by more affluent members of their society this can undermine their perceptions of self-worth or claims to equal status. As Judith Lichtenberg notes, there is 'an expressive aspect to such deprivations - they say something about and to poor people in rich societies - that turns insult into injury' (Lichtenberg 2014, p. 163). However, where homeless individuals are regularly ignored by passers-by, who avoid eye contact and refuse to enter into conversation with their less fortunate compatriots, this also plausibly communicates a lack of concern to other passers-by. The expressive aspect of this behaviour is compounded by the sheer scale, as hundreds, if not thousands, stream past the homeless, who sit unacknowledged, in our great cities.

A second mechanism occurs through the broader tolerance of these injustices by society as a whole. Within democratic societies, a failure to address injustices though democratic processes communicates the same message, of a lack of concern, but on a larger scale. The communicative aspect primarily derives from a lack of action to address injustices, rather than successfully addressing injustices, as political will does not always translate into successful action in the case of complex policy problems. However, homelessness is a severe injustice that has shown itself to be amenable to correction, where the political will exists (Gray 2018). Moreover, although Judith Shklar (1990, p. 45) rightly observes that we may tolerate certain injustices for the sake of other positive social goods, and in doing so express concern or compassion for our fellow citizens, I take this mechanism to be implausible in the case of homelessness due to the normative significance of the basic goods homeless individuals are unable to access.

Thirdly, our own individual failure to address national injustices such as homelessness can serve to weaken our individual commitments to universal values. Social psychology research suggests that individuals are typically troubled by cognitive dissonance when their beliefs and actions fail to cohere, and that to achieve consistency we often alter our beliefs rather than our actions. As Stoker notes, 'Following Festinger (1957) psychologists suggest that people seek consistency between their beliefs and their behaviour. However, when beliefs and behaviour clash, we frequently alter our beliefs instead of adjusting our behaviour' (2014, p. 227). Accordingly, regularly failing to address injustices encountered in person may lead to the weakening of individual commitments to universal values. 
By acknowledging the role of tolerance of national injustices in undermining levels of motivation to address global injustice, this argument can address a compelling objection to sentimental cosmopolitanism more broadly; that many people draw the boundaries of their moral community at a level that excludes not just individuals beyond national borders, but many of their own co-nationals. To put this objection pejoratively: 'How can we expect to encourage affective concern for people beyond national borders, when people are barely moved by the plight of the homeless individuals that they walk past on the street every day?' However, what this objection fails to consider is that attitudes to homelessness are not fixed, and that current levels of tolerance of homelessness and other injustices at the national level play a significant role in compounding and entrenching the restriction of the extension of affective concern.

The three mechanisms I have outlined operate where behaviour that appears to tolerate injustice within national borders serves to undermine commitment to cosmopolitan values. However, I now want to suggest that the pernicious influence of such behaviour on our values may go further, conditioning the reach and motivational power of our moral concepts. In particular, I want to suggest that tolerance of homelessness and other significant injustices at the national level can impede the work that appeals to a shared humanity can do in motivating cosmopolitan concern.

In his seminal work A Common Humanity, Raimond Gaita argues that the limits of our understanding of common humanity, understood as an affective notion delineating membership within our moral community-who we feel to be 'one of us' (Gaita 2000) — can be expanded or contracted through the patterns of behaviour prevalent within our society. To illustrate, Gaita offers the example of racism, arguing that where racist behaviour is common in a society this can serve to render a particular group of human beings invisible to the moral faculties of their fellows (Gaita 2000, p. xx). The thought here is that identification as a member of this moral community is necessary for rational moral argument to gain purchase, and that rather than being co-extensive with biological membership of the species Homo sapiens, the limits of this concept are conditioned through behaviour. Tolerance of homelessness, and other significant injustices, within national borders can serve to drive a wedge between membership of the human species and identification within an affective understanding of shared humanity. Gaita gestures towards the exclusion of the homeless from within this identification, approvingly quoting the parsing of a line from a Spanish folk song by the French philosopher Simone Weil: 'If you want to become invisible, there is no surer way than to be poor' (Gaita 2000, p. xx). This exclusion is especially damaging for sentimental cosmopolitan strategies that aim to proceed in the opposite direction, bringing the affective recognition of shared humanity closer in line with the limits of the biological concept.

\section{Objections}

I have argued that tolerance of injustice at the national level has an expressive content that may undermine respect for cosmopolitan values, serving to limit the work that the bare fact of shared humanity can do in motivating affective concern 
for distant others. However, it may be objected that this argument suffers from the following four significant flaws. (i) This argument ignores the role judgements of responsibility for suffering play in the development of affective concern. (ii) Direct encounters with injustices within national borders are typically distributed unevenly between the more affluent and less affluent members of society. Accordingly, this argument appears to suggest that the less affluent are particularly responsible for the motivational failure to address global poverty. (iii) Tolerance of homelessness within a society need not imply tolerance of injustice, as profound inequality of outcome may be compatible with justice, at least on some conceptions. (iv) Perhaps exposure to homelessness does undermine cosmopolitan sentiment, but through the alternative mechanism that people exposed to homelessness within national borders tend to entertain thoughts of the form: 'well, we have our own problems here to worry about, so why should I worry about problems abroad?' I will address each objection in turn.

The first objection claims that there is an important dis-analogy between how the situation of individuals facing global poverty and individuals facing homelessness, and other injustices, within affluent countries are perceived. There may be a popular perception that the homeless within affluent countries are in some sense responsible for their situation, failing to take advantage of opportunities available to them, whereas impoverished people in less affluent countries suffer due to political instability and a lack of functioning institutions and opportunities for employment. I am suggesting that this perception means that tolerance of homelessness within national borders need not imply a lack of affective concern for individuals facing poverty globally, not that this is an accurate characterisation of the situation of impoverished people in affluent countries.

There will be cases where this objection obtains, as we have to allow for the possibility that some people will be more motivated to address injustices at a global level rather than a national level, and that judgements of responsibility may play a role in their reasoning. For these individuals, the arguments of this paper will have little relevance. However, the significance of this point is limited, as such cases are not typical. Instead, we are more regularly confronted by either a greater level of motivation to address the suffering of co-nationals or a lack of motivation to address injustices whatsoever. Often, attributions of responsibility to those suffering significant injustices within affluent countries will be misinformed or fail to take into account that poor choices typically only lead to homelessness for individuals who lack robust safety nets (Equality and Human Rights Commission 2016). In these cases, there is an important role for critical reason within sentimental cosmopolitan approaches, not only in directing our motivation to address injustices towards the most effective solutions (Woods 2012, p. 40), but also in removing barriers to the extension of affective concern. Despite this, there may still be individual cases where critical reflection reinforces judgements of responsibility for suffering. Here, it is important to note that attempting to separate causal responsibility from moral responsibility does not provide an easy solution. As Bernard Williams argues, for most of us, most of the time, judgements of causal responsibility cannot be fully disentangled from attributions of moral responsibility, especially so at the level of affect (Williams 1993). However, these individual cases need not pose a serious 
threat to my argument. Where support for policies addressing homelessness and other significant injustices within national borders is threatened by judgements of responsibility, these are general judgements regarding the group in question rather than judgements in individual cases. Accordingly, critical attention to broader patterns of responsibility for injustice still represents an effective remedy.

The second objection argues that if regular experience of injustices within national borders is thought to play a role in undermining cosmopolitan commitments, this suggests that those who regularly witness injustices in person represent a particular barrier to the extension of cosmopolitan concern. The worry here is that exposure to injustices within unequal societies is typically distributed unevenly based on wealth and class and other inequalities. As such, my argument appears to blame the less affluent members of affluent societies for the motivational failure to address global injustices. However, what this objection fails to acknowledge is that the patterns distributing personal exposure to suffering others within a society are neither random nor the choice of less affluent members of society. For example, where homeless people are prevented from congregating in affluent neighbourhoods, this is due either to the result of political decisions that affect the more and less affluent members of a society unequally or, perhaps more typically, the unequal enforcement of the outcomes of these political processes. Therefore, responsibility for any negative effects of unequal exposure to injustices within a society, does not lie with the less affluent individuals themselves. Moreover, this objection only applies to cases where tolerance of injustices within national borders is witnessed in person. It does not affect the institutional component of my argument, where tolerance of injustice is reflected in a failure on the part of citizens to address these injustices through democratic institutions.

The third objection claims that the profound equality of outcome evidenced by homelessness need not be the result of an injustice, for example on a libertarian account (as noted above). Although I take inequality of outcome to be compatible with justice in some cases, I do not think this applies in the case of serious deprivations such as homelessness. Therefore, I do not agree with the substantive account of justice underpinning this objection. However, rather than defending this particular conception of justice I instead offer the following three responses. First, whilst some homelessness in affluent societies may indeed result from poor choices compatible with equality of opportunity, it is implausible to suggest that affluent societies currently exhibit equality of opportunity. Accordingly, actually existing homelessness is typically evidence of injustice, even on an account of justice that subordinates equality of outcome in favour of equality of opportunity. Second, there is significant empirical evidence (Nishio et al. 2017) that treatable mental health issues are a major factor in individuals becoming homeless. This suggests that actual existing homelessness will not be compatible with justice as equality of opportunity. Third, my argument applies where profound equality of outcome is not understood as injustice, strictly conceived, as a society that tolerates profound inequality of outcomes, including homelessness, is likely to be one in which cosmopolitan values struggle to gain traction.

The fourth objection states that exposure to homelessness within national borders does undermine cosmopolitan sentiment, but via thoughts of the form 'we have 
our own problems to worry about, so why should I worry about problems abroad?', rather than through the mechanism I have outlined. ${ }^{3}$ The first point to note here is that it does not undermine my broader argument if thoughts of this form are responsible for a lack of motivation to address global injustice, as this mechanism still supports the conclusion that addressing severe injustices (such as homelessness) within the borders of affluent countries is plausibly necessary in order to further cosmopolitan aims. Secondly, I do not deny that both mechanisms are likely to be operative. However, there is reason to think that the former mechanism is less plausible, as it strongly suggests that people typically react to the homeless in a positive manner; for example as fellow compatriots who have fallen on hard times. Empirical studies examining our psychological reactions to the homeless significantly undermine this conclusion. Research from social psychology highlights that we typically react to homeless individuals with the 'non-person treatment'-refusing to engage emotionally or practically with their situation (Lankenau 1999; Anderson et al. 1994), rather than with affective concern. This view receives further support from medial prefrontal cortex studies within neuroscience, which suggest that many people fail to perceive the homeless as fellow human beings with the medial prefrontal cortexthe part of the brain responsible for social cognition-failing to react in response to homeless individuals (Harris and Fiske 2006). It is beyond the scope of this article to decisively settle the empirical question in favour of either mechanism. However, I have suggested some reasons for thinking that the account I have offered is plausible, and hope to have, at least, presented a novel alternative mechanism by which national injustices can limit action to address global injustice, that is of particular significance for sentimental cosmopolitan accounts.

\section{Caring Institutions and Cosmopolitan Concern}

Having examined the ways in which national injustices present a barrier to motivating global justice I now turn to the positive side of the coin. In this section I examine how the pursuit of justice within national borders may directly further sentimental cosmopolitan goals by providing an environment conducive to the development and maintenance of cosmopolitan concern. This is alongside the direct relevance addressing injustices within the borders of more affluent countries has for cosmopolitans, as these injustices themselves constitute instances of global injustice. Proponents of a cosmopolitan sentimental education have argued that educational institutions and the media have an important role to play in encouraging the extension of sentimental concern beyond national borders (Nussbaum 2001). This is highly important. However, this focus neglects the prior question of the conditions within a polity that are conducive to the development of compassionate dispositions more broadly. In the third section of this article I argue that social institutions that exist at the national level, in particular what might be termed caring institutionsthose dealing with the provision of health and social care-are vital for creating a

\footnotetext{
3 I thank an anonymous reviewer for this suggestion.
} 
compassionate citizenry, disposed to help not only fellow citizens, but also distant others.

\section{The Didactic Role of Caring Institutions}

Discussions of sentimental cosmopolitanism have tended to focus on the role of educational institutions, the media and popular art, both as a means of encouraging emotional identification with distant others and extending our general capacity for responding to the sufferings of others with affective concern (Nussbaum 2001; Rorty 1998). Although these factors are highly important, I want to suggest that other national institutions play an important role in creating compassionate citizens disposed to respond with affective concern when confronted by instances of suffering, both within and beyond national borders. To be clear, narrative art forms and journalism are particularly important in expanding the constituency of individuals with whom we readily identify (Nussbaum 2001); however, other factors plausibly influence our tendency and capacity to respond affectively to suffering. In particular, I want to suggest that the existence of effective caring institutions within a society, such as those offering medical and social care, will be conducive to the development of compassionate citizens. These institutions can perform an educative function, teaching individuals to behave in a compassionate manner and to view other human beings in a certain light. As Raimond Gaita suggests, this contains both a negative and a positive element: 'The struggle for social justice...is the struggle to make our institutions reveal rather than obscure, and then enhance rather than diminish, the full humanity of our fellow citizens' (Gaita 2000, p. xxi). Having examined the negative aspect in the previous section, I now focus on the positive element.

There are three mechanisms through which caring institutions can perform this function. First, the values that these institutions are seen to embody can directly perform an educative function. For example, where hospitals offer high quality care to all patients, this can serve to reinforce the idea that all persons are owed certain basic goods regardless of wealth or background; something that, in the right circumstances, supports the teaching of cosmopolitan values within formal processes of sentimental education. Support for the effectiveness of this approach can be derived from social psychological studies suggesting that where injunctive norms-learnt through instruction and descriptive norms-based on the patterns of behaviour prevalent in a society conflict, the latter typically overwhelm the former (Campbell-Arvai et al. 2014, p. 469). This is not to suggest that attempts to teach values within formal education are unimportant, but that individuals will be more receptive to these values if they are seen to be embodied in the practices of the society in question.

Second, the behaviour of the individuals who staff caring institutions can perform an educative function, teaching compassion to those who encounter it, either directly - as the subject of the care, or indirectly - for example, when visiting a loved one in a hospital or a care home. As theorists in the tradition of virtue ethics have argued, we learn moral values most effectively when we witness them in the behaviour of virtuous exemplars (Kristjansson 2014). This also receives significant empirical support from research in educational psychology 
(see Kristjansson (2015) for a review of the evidence). The words and behaviour of individuals who work in caring professions may also have particular authority in teaching compassion. This is because the words and behaviour of these individuals will derive additional authority from these individuals' lived experience of demanding situations that call for and test this particular virtue (Gaita 2000, p. xxxvi). Of course, where staff in these institutions fail to treat individuals receiving care (broadly conceived) with respect then the converse will apply. However, I do not take this to be typical.

Finally, being treated with compassion is typically thought to increase our own propensity to act compassionately. This insight is perhaps most associated with Okin's work on the need for certain virtues to be present within the family in order for a society to effectively create just citizens (Okin 1989). However, as Matt Edge has argued, interactions within a society will also condition the extent to which individuals are disposed to respond with empathy or compassion to the sufferings of others (2016, pp. 115-119). This is supported by social psychology research suggesting that being the subject of caring behaviour reliably leads to an increased stable disposition to act in a compassionate manner (Edge 2016, p. 116; Mikulincer et al. 2005, p. 837). It is important to note that whilst the first mechanism only requires knowledge that caring institutions exist within a given society, the latter two mechanisms require personal experience of caring institutions to be operative. This is something that is a feature of most individuals' lives, especially at the start of life, with children being exposed to health services in various ways; for example, through vaccination programmes or doctor's appointments. Similarly, exposure to social and medical care is typically prevalent in the latter stages of life. However, many individuals are regularly exposed to health and social care throughout their lives, and parents are exposed to these services through their children.

Michael Ignatieff raises an important potential objection that applies to the latter two mechanisms I have offered, in his seminal discussion of the welfare state, The Needs of Strangers (1984). In this book, Ignatieff argues that a significant advantage of the institutions of the welfare state is that they function to mediate networks of giving and receiving within a society, such that those receiving care are not only claiming what they are owed but perceive themselves as doing so. This may be thought to undermine perceptions of individuals working within these institutions as behaving in a compassionate manner, and accordingly the success of the second and third mechanisms, as rather than behaving compassionately they are delivering what is owed. However, there is no direct contradiction here, as individuals can be owed caring behaviour, and, although the duties of individual citizens are institutionalised and discharged via the welfare state rather than through private charity, it is the individuals working in these institutions whose behaviour is relevant on the mechanisms I have outlined. I take it that (these) individuals can, and do, behave in a compassionate manner when operating in a professional capacity, and that their behaviour be interpreted as such. Conversely, an emphasis on the care delivered by the welfare state as something that is owed potentially serves to reinforce the first mechanism (where these institutions perform an educative function), strengthening commitments to the idea that people are owed certain basic goods, such as health and social care, regardless of wealth or background. 


\section{Sympathy and Security}

Finally, I want to suggest that institutions promoting justice within the borders of more affluent nations can lead their citizens to be more receptive to strategies of sentimental education more indirectly, by increasing citizens' perceptions of their relative security. This argument derives from Richard Rorty's claim that strategies of sentimental education will fail to gain purchase where individuals feel their own security is under threat. Rorty (1998, p. 180) argues that in conditions where our security is under threat our first concern is ourselves, and those with whom we immediately identify; accordingly, our horizons are narrowed, and we can less afford the time and effort to imaginatively engage with the lives of distant others. Ultimately, the claim Rorty is making here is an empirical one; however, it is a claim that I take to be intuitively plausible. As Woods notes in a paper defending the relevance of Rorty's security condition in understanding the causal role of environmental degradation in the under-fulfilment of human rights, 'where one's own security is threatened, one's first concern is normally for oneself' (Woods 2009, p. 62). This is a claim that can plausibly be broadened to include the security of the subjects of our partial commitments, such as close friends or family.

In endorsing Rorty's claim it is important to acknowledge that vulnerability is a fundamental component of human life. Moreover, as Rousseau suggested (1991, p. 185), vulnerability is plausibly bound up in the extension of compassion. However, this does not imply that individuals cannot take reasonable steps to limit their own vulnerability. Neither does it imply that awareness of one's own vulnerability will lead us to address the vulnerabilities of distant others rather than individuals for whom we already feel a great degree of affective concern. Moreover, both Rorty's broader point and the inclusion of the safety of those closest to us within the security condition receive significant empirical support from social psychology research into the role of stress responses in blocking empathetic behaviours. As Paul Zak argues, 'nature assumes that if we are in dire straits ourselves, we can't so easily afford to invest time and resources in helping others. High stress blocks oxytocin release' (Edge 2016, p. 238; Zak 2012, p. 64).

If we accept that Rorty's security condition is an important factor in determining the acceptance of strategies of cosmopolitan sentimental education, then this suggests that levels of injustice within national borders will directly affect the success of sentimental cosmopolitan approaches. There are two mechanisms through which this process can occur. In a relatively straightforward manner, a failure on behalf of affluent societies to provide access to effective health and social care will directly undermine perceptions of security on behalf of those individuals unable to access this care for themselves and those closest to them. We should note that within affluent societies ill health (of various forms) and infirmity are typically the greatest threats to individual security. However, what is actually doing the work on Rorty's account is not simply security in an absolute sense, but perceptions of relative security on behalf of individuals. Therefore, the existence of significant levels of inequality within national borders may also play a role in undermining perceptions of security within a society and, as such, the success of strategies of cosmopolitan sentimental education. Empirical support for this broad claim can be found 
in an extensive literature on the positive role of the welfare state in generating support amongst the citizenry for the admittance of greater numbers of refugees (Crepaz 2008; Van Oorschot and Uunk 2007).

Conversely, where societies are highly unequal this can undermine perceptions of security on the part of all but the most affluent members of society. As previously noted, relative deprivation within a society can both have an expressive function, conveying a lack of worth to the less afluent, and translate into absolute deprivations in access to certain goods-such as self-worth or autonomy (Lichtenberg 2014, pp. 163-164). This can lead to reduced perceptions of security, and to reductions in absolute security in some cases. Where inequalities in wealth translate into, or are accompanied by, significant power differentials this can directly affect an individual's ability to exercise agency over their own life. In some cases this can directly lead to a decrease in absolute levels of security. The effects on physical health of a lack of agency in the workplace, for example, are well documented (Lichtenberg 2014, p. 162; Marmot 2004). More typically, power differentials can undermine absolute levels of security through one's relative ability to compete for certain scarce goods, such as the best quality health and social care. Significantly, where fellow citizens are taken as an individual's reference group, inequality in access to advances in medical treatment may undermine perceptions of relative security to a greater extent than inequalities in access to medical treatment across borders. For example, where the more affluent members of society can access cutting-edge cancer treatments, an inability to access these treatments will undermine perceptions of security on the part of those who cannot. ${ }^{4}$

It might be objected that perceptions of security have more to do with the content of the media than the availability of adequate health and social care within a society. Here, national media might be thought responsible both for reinforcing perceptions that co-nationals are our primary reference group and devoting attention to highlighting inequalities within societies rather than between them. The tone of media discourse also arguably plays a significant role in how secure citizens perceive themselves to be. Where media reporting focuses on imagined crises in national institutions, for example, this is likely to undermine citizens' perceptions of their relative security. There is some truth to this line of argument, as the media will clearly play an important role in shaping citizens perceptions of relative security; however, this should not be overstated. Perceptions of relative security are likely to bear some relationship to a more objective understanding of security, based on the actual conditions existing in a given society. Although important, the force of this objection is further limited as media serving to increase perceptions of insecurity will only be regularly consumed by certain groups within society. Within liberal democracies the media typically offers a broad range of perspectives, and it is unlikely that these will all serve to reinforce perceptions of insecurity. We should also note the increasing role of non-traditional media, operating across borders, both in undermining

\footnotetext{
${ }^{4}$ In some cases the converse will be true, with perceptions of security on the part of majorities being increased by the promotion of national injustices, targeting minorities where these minorities are perceived as a security risk. For example, illiberal security measures targeting minority groups.
} 
co-nationals as an individual's primary reference group, and potentially increasing perceptions of relative security through global, rather than national, comparisons.

\section{Objections}

It might be objected that the basic empirical claim I am making here is false, and that the existence of caring institutions within a society has little, or no, effect in increasing the propensity of individuals to respond to the sufferings of others with compassion or affective concern. A full empirical defence of this claim is beyond the scope of the article, but I take this to be an intuitive point, and have provided some support for this position in the empirical claims canvassed above. As noted previously, there is a clear link between being the subject of caring behaviour and developing a compassionate disposition (Edge 2016; Mikulincer et al. 2005). This link remains when we experience caring behaviour through welfare state institutions (Kumlin 2004). Further empirical support for a positive relationship between welfare state institutions and levels of cosmopolitan compassion can be found in research showing a strong link between citizenship of a welfare state and support for policies to address injustices facing distant others. For example, studies by Noel and Therien (1995) show a broad trend where citizens of welfare states support higher levels of government spending on foreign aid. This is corroborated in a more recent survey by Kharas and Noe (2018), which shows that high domestic welfare spending correlates with high levels of international aid spending, although the direct role of public attitudes here is less clear. Most promisingly, the latest OECD report on the topic offers direct support, concluding that 'welfare state institutions create public support for foreign aid' (Zimmerman 2007). Outside of aid spending, further empirical support for a link between domestic welfare states and public support for cosmopolitan policies is suggested in literature on the role of welfare states in generating support amongst the citizenry for the admittance of greater numbers of refugees (Crepaz 2008; Van Oorschot and Uunk 2007). I cannot decisively settle the empirical case here, but these studies suggest that the model outlined in the article is at least plausible. However, there are two further potential objections that require answering in detail. (i) That these institutions play a role in creating compassionate citizens, but will typically lead to insular caring communities rather than the extension of cosmopolitan concern. (ii) That the argument advanced here is just too convenient, explaining away a real conflict at the level of motivation between global and national justice. I will address each point in turn.

In response to the first objection, I do not want to deny the existence of insular communities, where individuals show a significant level of sentimental concern for their fellow citizens but little concern for individuals beyond national borders. However, I take this to be a less common phenomenon than cases where societies fail to meet these standards both externally and internally. There is also some correlation between strong welfare states and significant levels of public support for relatively high levels of international aid spending (Noel and Therien 1995). More significantly, this objection misunderstands the role I am suggesting for institutions offering health and social care at the national level in increasing cosmopolitan 
concern. I am suggesting that we need both caring institutions at the national level and strategies of cosmopolitan sentimental education. Where the former serves to increase receptiveness to strategies of cosmopolitan sentimental education, and the latter operates to correct a tendency for compassionate dispositions to be parochial.

It may be argued that the objection posed by insular caring communities is in fact more damaging than I have suggested, being grounded in our evolutionary biology. Philosophers such as Kitcher (2014) and Heath (2012), drawing on evolutionary studies by Tomasello (2016), argue that humans developed an in-group conception of morality that allowed us to successfully co-operate and compete against other groups of humans. Thus, given that in-group morality has played such an important role in humanity's evolution, the scope of moral concern may not only be limited, but necessarily directed towards members of particular in-groups. ${ }^{5}$

Even if it is the case that our moral concern for others requires a correlate outgroup for evolutionary reasons, out-groups need not consist of humans spatially distant from ourselves. ${ }^{6}$ As Arash Abizadeh notes, '[d]ifference need not refer to actually existing persons at all: it can refer to nonhumans, it can refer to characteristics not individuals, and it need not refer to actually existing things at all' (Abizadeh 2005 , p. 57). Therefore, accepting this evolutionary picture of moral development need not undermine the plausibility of extending affective connections to distant others. However, there are good reasons for rejecting this bleak evolutionary picture in favour of a more nuanced view of the origins of morality, while still taking an evolutionary approach. For example, Buchanan and Powell (2018) offer an evolutionary account of the origins of morality that allows for inclusivist moral progress. As they write:

[T]here is good reason to believe that humans, rather than being hard-wired for exclusivity, have a momentous moral plasticity - a capacity for both exclusivist and inclusivist response- that is shaped by biology, culture, or (most likely) both. (p. 199)

On Buchanan and Powell's (2018) account, exclusivist moral concern is a part of our evolutionary history, but only arises when 'threat conditions', such as scarcity of food, are met. Outside of these conditions, inclusivist moral systems face no biological barriers. It is beyond the scope of this article to conclusively settle the debate between these differing evolutionary accounts of the development and plasticity of moral concern. However, the plausibility of strongly exclusivist accounts is undermined by the many clear examples of inclusivism, such as the spread of animal rights and cosmopolitan concern-as evidenced by charitable giving beyond borders. At the least, Buchanan and Powell's account shows that the argument offered in this paper is compatible with (at least) one evolutionary account of morality.

The second objection, that the model presented here dissolves the conflict between national and global justice, misunderstands my argument. I have claimed that the extent to which strategies of cosmopolitan sentimental education will be

\footnotetext{
5 I thank an anonymous reviewer for this objection.

6 Those unconvinced by evolutionary accounts of morality can ignore this objection and my response.
} 
effective will itself be dependent on institutions within national borders fostering an environment conducive to the development of compassion or affective concern. Rather than dissolving the conflict between national and global justice this is instead a case of accepting the hard conclusion that the promotion of justice within national borders is a necessary step in order for a cosmopolitan sentimental education to be effective. This is especially significant, as policies at the national and international level aimed at addressing global injustice require popular support in order to be effective, both to ensure that there is sufficient political pressure for these policies to be implemented and for the outcomes of democratic processes to remain stable.

\section{Conclusion}

This paper has examined the relationship between attempts to motivate citizens of more affluent countries to care about the fate of distant others facing severe injustices, such as global poverty, and levels of injustice within the borders of these affluent countries themselves. I have argued that the promotion of justice within the borders of more affluent countries and strategies of cosmopolitan sentimental education aimed at promoting global justice are potentially complementary rather than competing projects. In order to do so, I have defended two claims concerning the relationship between national injustice and cosmopolitan motivation-one negative and one positive. (i) Injustice within national borders can undermine the development of cosmopolitan concern and respect for the values that underlie the cosmopolitan project. (ii) Institutions within national borders responsible for delivering health and social care can play a role in developing and sustaining the empathetic/compassionate dispositions necessary for individuals in more affluent countries to care about the fate of distant others. Therefore, sentimental cosmopolitans ought to be concerned with addressing injustices within the borders of more affluent countries (not only for the intrinsic value of doing so), but as a means to develop and sustain the affective dispositions necessary to motivate citizens to act to address injustices elsewhere.

Acknowledgements I would like to thank Kerri Woods, Derek Edyvane, Luke Ulas and the participants at the MANCEPT 2019 workshop 'Cosmopolitan Motivation, Political Theory and Political Psychology' for helpful comments on previous versions of this paper. The paper has not been published previously in any form, and is not currently under consideration elsewhere.

\section{Declarations}

Conflict of interest I have no conflicts of interest to disclose.

Open Access This article is licensed under a Creative Commons Attribution 4.0 International License, which permits use, sharing, adaptation, distribution and reproduction in any medium or format, as long as you give appropriate credit to the original author(s) and the source, provide a link to the Creative Commons licence, and indicate if changes were made. The images or other third party material in this article are included in the article's Creative Commons licence, unless indicated otherwise in a credit line to the material. If material is not included in the article's Creative Commons licence and your intended use is not permitted by statutory regulation or exceeds the permitted use, you will need to obtain permission 
directly from the copyright holder. To view a copy of this licence, visit http://creativecommons.org/licen ses/by/4.0/.

\section{References}

Abizadeh, Arash. 2005. Does collective identity presuppose an other? On the alleged incoherence of global solidarity. American Political Science Review 99: 45-60.

Alain, Noel, and Jean-Philippe. Therien. 1995. From domestic to international justice: The welfare state and foreign aid. International Organisation 49: 523-553.

Anderson, Leon, David Snow, and Daniel Cress. 1994. Negotiating the public realm: Stigma management and collective action among the homeless. In Research in community sociology: Supplement 1: The community of the streets, ed. Dan Chekki, Spencer Cahill, and Lyn Lofland, 121143. Greenwich: JAI Press.

Batson, Daniel, Laurie Highberger, Tricia Klein, and Laura Shaw. 1995. Immorality from empathyinduced altruism: When compassion and justice conflict. Journal of Personality and Social Psychology 68: 1042-1054.

Buchanan, Allen, and Russell Powell. 2018. The evolution of moral progress: A biocultural theory. Oxford: Oxford University Press.

Burgi, Noelle. 2014. Societies without citizens. European Journal of Social Theory 17: 290-306.

Campbell-Arvai, Victoria, Joseph Arvai, and Linda Kalof. 2014. Motivating sustainable food choices: The role of nudges, value orientation, and information provision. Environment and Behaviour 46: 453-475.

Chong Alberto, Mark Gradstein (2006) Who's afraid of foreign aid? The donor's perspective. InterAmerican Development Bank. https://publications.iadb.org/publications/english/document/WhoAfraid-of-Foreign-Aid-The-Donors-Perspective.pdf. Accessed from 14 Jan 2021.

European Commission. Special Eurobarometer 222. Attitudes towards development aid. 2005. European Commission. https://ec.europa.eu/commfrontoffice/publicopinion/archives/ebs/ebs_222 sum_en.pdf. Accessed from14 Jan 2021.

Crepaz, Markus ML. 2008. Trust beyond borders: Immigration, the welfare state and identity in modern societies. Ann Arbor: The University of Michigan Press.

Edge, Matt. 2016. Political philosophy, empathy and political justice. Abingdon: Routledge.

Posner Eric (2017) Liberal internationalism and the populist backlash, University of Chicago Public Law \& Legal Theory Paper Series 606. https://chicagounbound.uchicago.edu/cgi/viewcontent. cgi?referer=https://scholar.google.com.au/\&httpsredir=1\&article=2071\&context=public_law_ and_legal_theory. Accessed from 20 Sep 2019.

Goodwin, Matthew, and Oliver Heath. 2016. The 2016 referendum, Brexit and the left behind: An aggregate-level analysis of the result. The Political Quarterly 87: 323-332.

Gray Alex (2018) Here's how Finland solved its homelessness problem. Weforum. https://www.wefor um.org/agenda/2018/02/how-finland-solved-homelessness. Accessed from 23 Jun 2019.

Greene, Joshua, R. Brian Sommerville, Leigh Nystrom, John Darley, and Jonathan Cohen. 2001. An fMRI investigation of emotional engagement in moral judgment. Science 293: 2105-2108.

Harris, Lasana, and Susan Fiske. 2006. Dehumanizing the lowest of the low: Neuroimaging responses to extreme out-groups. Psychological Science 17: 847-853.

Heath, Joseph. 2012. Letting the world in empirical approaches to ethics. Les Ateliers De L'éthique/ the Ethics Forum 7: 93-107.

Ignatieff, Michael. 1984. The needs of strangers. London: Hogarth Press.

Izard, Carroll, and Beier Ackerman. 2000. Motivational organisational, and regulatory functions of discrete emotions. In Handbook of emotions, ed. Michael Lewis and Jeanette Haviland-Jones, 253-264. New York: Guilford.

Jeffery, Renee. 2014. Reason and emotion in international ethics. Cambridge: Cambridge University Press.

Kharas Homi, Lorenz Noe (2018) The link between foreign aid and domestic social spending. Up Front. https://www.brookings.edu/blog/up-front/2018/02/01/the-link-between-foreign-aid-anddomestic-social-spending. Accessed from 14 Jan 2021. 
Kirstein, Rummery. 2016. Equalities: The impact of welfare reform and austerity by gender, disability and age. In The coalition government and austerity: Restructuring the welfare state, ed. Hugh Bochel and Martin Powell, 309-324. Bristol: Policy Press.

Kitcher, Philip. 2014. The ethical project. Harvard, MA: Harvard University Press.

Koenigs, Michael, Liane Young, Ralph Adolphs, Daniel Tranel, Fiery Cushman, Marc Hauser, and Antonio Damasio. 2007. Damage to the prefrontal cortex increases utilitarian moral judgements. Nature 446: 908-911.

Kristjansson, Kristjan. 2014. There is something about Aristotle: The pros and cons of Aristotelianism in contemporary moral education. Journal of Philosophy of Education 48: 48-68.

Kristjansson, Kristian. 2015. Aristotelian character education. Abingdon: Routledge.

Lankenau, Stephen. 1999. Panhandling repertoires and routines for overcoming the nonperson treatment. Deviant Behavior 20: 183-206.

Lenard, Patti. 2010. Motivating cosmopolitanism? A skeptical view. Journal of Moral Philosophy 7: 346-371.

Lichtenberg, Judith. 2014. Distant strangers: Ethics, psychology, and global poverty. Cambridge: Cambridge University Press.

Long, Graham. 2009. Moral and sentimental cosmopolitanism. Journal of Social Philosophy 40: 317-342.

Mario, Mikulincer, Phillip R. Shaver, Omri Gillath, and Rachel A. Nitzberg. 2005. Attachment, caregiving and altruism: Boosting attachment security increases compassion and helping. Journal of Personality and Social Psychology 89: 817-839.

Marmot, Michael. 2004. The status syndrome: How social standing affects our health and longevity. New York: Times Books.

McTernan, Emily. 2014. How to make citizens behave: Social psychology, liberal virtues, and social norms. The Journal of Political Philosophy 22: 84-104.

Nishio, Akihiro, Ryo Horita, Tadahiro Sado, Seiko Mizutani, Takahiro Watanabe, Ryosuke Uehara, and Mayumi Yamamoto. 2017. Causes of homelessness prevalence: Relationship between homelessness and disability. Psychiatry and Clinical Neurosciences 71: 180-188.

Nussbaum, Martha. 1996. Patriotism and cosmopolitanism. In For love of country?, ed. Joshua Cohen, 3-20. Boston, MA: Beacon Press.

Nussbaum, Martha. 2001. Upheavals of thought: The intelligence of emotions. Cambridge: Cambridge University Press.

Okin, Susan. 1989. Justice, gender, and the family. New York: Basic Books.

Ortiz-Ospina, Esteban. Max Roser. 2017. Homelessness. Our World in Data. https://ourworldindata. org/homelessness. Accessed from 14 Jan 2021.

Pogge, Thomas. 2002. World poverty and human rights: Cosmopolitan responsibilities and reforms. Cambridge: Polity Press.

Prinz, Jesse, and Shaun Nichols. 2010. Moral emotions. In The moral psychology handbook, ed. The Moral Psychology Research Group, 111-147. Oxford: Oxford University Press.

Raimond, Gaita. 2000. A common humanity: Thinking about love and truth and justice, 2nd edn. Abingdon: Routledge.

Rorty, Richard. 1998. Human rights, rationality, and sentimentality. In Truth and progress: Philosophical papers, vol. three, ed. Richard Rorty, 167-185. Cambridge: Cambridge University Press.

Rousseau, Jean-Jacques. 1991. Emile: Or on education. In Penguin classics edition. London: Penguin.

Shklar, Judith. 1990. The faces of injustice. New Haven, CT: Yale University Press.

Staffan, Kumlin. 2004. The personal and the political: How personal welfare state experiences affect political trust and ideology. New York: Palgrave Macmillan.

Stoker, Gerry. 2014. The politics of nudge: Dilemmas in implementing policies for sustainable consumption. In Sustainable consumption: Multi-disciplinary perspectives in honour of Professor Partha Dasgupta, ed. Alisdair Ulph and Dale Southerton, 224-239. Oxford: Oxford University Press.

Straehle, Christine. 2016. Falling into the justice gap? Between duties of social and global justice. Critical Review of International Social and Political Philosophy 19: 645-661.

Tiberius, Valerie. 2015. Moral psychology: A contemporary introduction. Abingdon: Routledge.

Tomasello, Michael. 2016. A natural history of human morality. Harvard, MA: Harvard University Press.

Van Oorschot, Wim, and Wilfred Uunk. 2007. Welfare spending and the public's concern for immigrants: Multilevel evidence for eighteen European countries. Comparative Politics 40: 63-82. 
Williams, Bernard. 1993. Shame and necessity. Berkeley: University of California Press.

Woods, Kerri. 2009. Suffering, sympathy, and (environmental) security: Reassessing Rorty's contribution to human rights theory. Res Publica. 15: 53-66.

Woods, Kerri. 2012. Whither sentiment? Compassion, solidarity, and disgust in cosmopolitan thought. Journal of Social Philosophy 43: 33-49.

Zak, Paul. 2012. The moral molecule. London: Bantam Press.

Zimmerman Robert (2007) The determinants of foreign aid: An inquiry into the consequences of welfare state institutions and public opinion. OECD. https://www.oecd.org/dev/40699467.pdf. Accessed from 14 Jan 2021.

Publisher's Note Springer Nature remains neutral with regard to jurisdictional claims in published maps and institutional affiliations. 